\title{
Corporate Social Responsibility PT. Madubaru 2010-2015
}

\author{
Oleh: \\ Choirul Fajri, S.I.Kom, M.A \\ (Program Studi Ilmu Komunikasi UAD/choirulfajri@yahoo.co.id)
}

\begin{abstract}
ABSTRAK
Program Corporate Social Responsibility (CSR) merupakan sebuah program yang wajib dijalankan oleh suatu perseroan terbatas (PT).CSR sebagai sebuah tanggung jawab sosial perusahaan, merupakan sebuah terobosan untuk menjalin hubungan baik dengan masyarakat.Pemerintah sendiri telah mewajibkan dan mengatur pelaksanaan program CSR ini melalui Undang-Undang Perseoran Terbatas Tahun 2002.Sebagai badan usaha milik negara (BUMN), PT Madubaru tentunya juga melaksanakan program ini.Penelitian ini sendiri merupakan penelitian lanjutan yang pernah peneliti lakukan di tahun 2010 lalu, yakni mengenai Community Relations PG/PS Madukismo. Di mana dalam penelitian ini, melihat bagaimana strategi-strategi yang dilakukan oleh PG/PS Madukismo dalam melaksanaan program ini, sebuah sebuah cara untuk memberikan kemanfaatan bagi masyarakat. Dalam melakukan penelitian ini, peneliti memilih menggunakan metode studi kasus, guna menjawab pertanyaan-pertanyaan mengenai bagaimana proses perencanaan, pelaksanaan, dan evaluasi program CSR tersebut. Dari hasil penelitian di dapatkan data, bahwa PT Madubaru telah melaksanakan program CSR tersebut dengan baik, adanya keterlibatan dari masyarakat, dan upaya-upaya pengembangan masyarakat. Hanya saja, upaya untuk membuat pelaporan kegiatan dengan memanfaatkan teknologi komunikasi seperti sekarang ini masih belum tampak.Padahal upaya tersebut, dapat digunakan untuk mencari feedback terkait dengan program yang telah dilaksanakan kepada masyarakat luas.
\end{abstract}

Kata kunci: CSR, PT Madubaru, Strategi

\section{A. Pendahuluan}

PT Madubaru merupakan salah satu perusahaan besar yang ada di Yogyakarta.Selain memproduksi gula, PT Madubaru juga memproduksi ethanol atau spritus.Di tengah persaingan industri yang kian memanas, PT Madubaru tetap bisa bertahan hingga saat ini.Hal ini, dikarenakan adanya prinsip Good Coorporate yang senantiasa diterapkannya. Dengan prinsip tersebut,PT Madubaru tetap dapat melayani masyarakat akan kebutuhannya terhadap gula di tengah himpitan krisis yang kini melanda. Krisis utama di pabrik ini adalah kurangnya bahan dasar pembuatan gula, yakni tebu untuk dapat diolah menjadi gula padahal setiap hari kebutuhan gula selalu meningkat. Salah satu hal penyebabnya, adalah berkurangnya jumlah tebu dalam setiap musim panen karena kemarau ataupun hama. (Saputro, 2005: 5)

Program Corporate Social Responsibility diwujudkan dalam Program Bina Lingkungan bagi masyarakat sekitar.Dengan dilakukan secara berkesinambungan dan tersruktur, program ini mampu menarik perhatian dan terbukti ampuh untuk menjalin suatu hubungan yang baik serta membentuk citra positif bagi masyarakat sekitar. Hal ini terbukti, dari setiap adanya permasalahan perusahaan yang menyangkut kepentingan dengan masyarakat sekitar (seperti masalah limbah diatas), mereka senantiasa mampu mengatasinya dengan baik tanpa adanya aksi-aksi anarkis dari masyarakat.

Program-program Corporate Social Responsibility tersebut senantiasa dilaksanakan dengan penuh kesadaran sebagai sarana untuk membina hubungan baik 
dengan masyarakat sekitar. Bahkan saat terjadi permasalahan terkait dengan limbah mereka pun, perusahaan tetap melaksanakan program-program tersebut, dan tidak berusaha menyalahkan masyarakat namun berusaha mencari jalan keluar guna menyesaikan masalah tersebut. Untuk mewujudkan tanggung jawab sosialnya ini PT Madubaru tidak melakukannya sendiri, namun mereka melakukan kerjasama dengan petani, pemasok, industri berbagai lembaga pemerintah, pemerintah daerah serta non pemerintah, menggarap berbagai isu yang sedang berkembang di tengah masyarakat sekitar. Dengan demikian PT Madubaru memang telah dapat mewujudkan berbagai program bagi masyarakat yang selama ini dikenal dengan program Bina Lingkungan.

Inilah yang kemudian menjadi menarik untuk diteliti yakni tentang strategi-strategi yang diterapkan PG Madukismo dalam program Corporate Social Responsibility terkait dengan berhasil ataupun tidaknya program tersebut dalam membina hubungan baik dengan masyarakat sekitar. Di mana dalam pelaksanaan program tersebut mempunyai tantangan tersendiri, yakni apakah program CSR yang diterapkan hanya sekedar melaksanakan kewajiban sebagaimana yang diterapkan oleh Pemerintah ${ }^{1}$ semata ataukah benar-benar program yang dibuat dengan penuh kesadaran untuk memberikan kemanfaatan bagi masyarakat.

\section{B. Kerangka Pemikiran}

Guna melakukan analisis terhadap hasil penelitian ini, peneliti mengambil beberapa teori maupun konsep-konsep mengenai Corporate Social Responsibility, sebagai berikut:

\section{Corporate Social Responsibility}

Corporate Social Responsibility merupakan sebuah pendekatan di mana perusahaan mengintegrasikan kepedulian sosial dalam operasi bisnisnya dan dalam interaksi dengan para pemangku kepentingan (stakeholders) berdasarkan prinsip kesukarelaan dan kemitraan (Nuryana, 2005).

CSR didefinisikan pula sebagai tanggungjawab sebuah organisasi terhadap dampak-dampak dari keputusan-keputusan dan kegiatan-kegiatannya pada masyarakat dan lingkungan yang diwujudkan dalam bentuk perilaku transparan dan etis yang sejalan dengan pembangunan berkelanjutan dan kesejahteraan masyarakat, mempertimbangkan harapan pemangku kepentingan, sejalan dengan hukum yang ditetapkan dan norma-norma perilaku internasional, serta terintegrasi dengan organisasi secara menyeluruh (draft 3 ISO 26000).

\footnotetext{
${ }^{1}$ Sebagaimana kita ketahui bersama, bahwa Pemerintah telah mengatur pelaksanaan CSR bagi Perseroan Terbatas (PT) dengan sedemikian rupa melalui Undang Undang Perseroan Terbatas Tahun 2007.Di mana setiap PT diwajibkan untuk melaksanakan program CSR tersebut.Bagi Perusahaan Milik Negara (BUMN) seperti halnya PG Madukismo, pelaksanaan program CSR juga telah ditetapkan pelaksanaannya oleh pemerintah yakni dalam bentuk Program Kemitraan dan BIna Lingkungan.
} 
Diterbitkan oleh Program Studi IImu Komunikasi

Universitas Ahmad Dahlan Yogyakarta

Terdapat 6 (enam) kategori aktivitas CSR (Kotler and Lee, 2005), sebagai berikut: a. Cause Promotions

Merupakan program CSR yang dilaksanakan perusahaan dalam penyediaan dana atau sumber daya lainnya yang dimiliki perusahaan guna meningkatkan kesadaran masyarakat terhadap suatu kegiatan sosial, atau mendukung pengumpulan dana, partisipasi dari masyarakat atau perekrutan tenaga sukarela untuk suatu program tertentu.

\section{b. Caused Related Marketing}

Aktivitas CSR cause related marketing adalah perusahaan memiliki komitmen untuk menyumbangkan presentase tertentu dari penghasilannya untuk suatu program sosial berdasarkan pada penjualan produk.

\section{c. Corporate Social Marketing}

Perusahaan mengembangkan dan melaksanakan kampanye untuk mengubah perilaku masyarakat dengan tujuan meningkatkan kesehatan dan keselamatan publik, menjaga kelestarian lingkungan hidup, serta meningkatkan kesejahteraan masyarakat.

d. Corporate Phylanthropy

Dalam jenis ini, perusahaan biasanya memberikan sumbangan langsung dalam bentuk derma untuk suatu kalangan masyarakat.

\section{e. Community Volunteering}

Dalam jenis ini biasanya perusahaan mendukung dan mendorong para karyawan, rekan pedagang eceran, atau para pemegang franchise agar menyisihkan waktunya secara sukarela guna membantu organisasi-organisasi masyarakat lokal maupun masyarakat yang menjadi sasaran dari masing-masing program.

\section{Kewajiban Perusahaan dalam Melaksanakanan CSR}

Pemerintah telah mengatur pelaksanaan dari CSR ini sendiri melalui UndangUndang Perseroan Terbatas No 40 Tahun 2007. Di dalam UU tersebut telah diatur mengenai tanggung jawab social perusahaan atau yang biasa disebut CSR, misalnya saja pada Pasal 74 UU PT No 40 Tahun 2007, sebagai berikut:

a. Perseroan yang menjalankan kegiatan usahanya di bidang dan atau berkaitan dengan sumber daya alam wajib melaksanakan tanggung jawab social dan lingkungan.

b. Tanggung jawab social dan lingkungan sebagaimana dimaksud pada ayat (1) merupakan kewajiban perseroan yang dianggarkan dan diperhitungkan sebagai biaya perseroan yang pelaksanaannya dilakukan dengan memperhatikan kepatutan dan kewajaran

c. Perseroan yang tidak melaksanakan kewajiban sebagaimana dimaksud pada ayat (1) dikena sanksi sesuai dengan ketentuan peraturan perundang-undangan

d. Ketentuan lebih lanjut mengenai tanggung jawab sosial dan lingkungan diatur dengan Peraturan Pemerintah.

Sebagaimana sudah disinggung di awal, bahwa CSR merupakan sebuah komitmen yang harus dijalankan secara berkelanjutan dari suatu perusahaan untuk berperilaku sesuai dengan aturan-aturan yang telah ditetapkan, serta dapat memberikan hal positif, baik 
kepada karyawab, komunitas, maupun lingkungan sekitarnya, juga masyarakat luas. Dengan kata lain, bahwa selain perusahaan mempunyai kewajiban ekonomis kepada para stakeholders, namun juga dapat memberikan perhatian kepada mereka.

Menilik perkembangan CSR, sebenarnya ini bukanlah suatu hal yang baru.Mengingat CSR telah muncul dari tahun 1953, di mana saat itu tulisan Howard Bowen (Social Responsibility of the Businessmen) dipaparkan dalam acara resmi akademik. Kala itu Bowen mepaparkan bahwa CSR adalah kewajiban dari para pelaku bisnis, di mana dalam membuat dan mengambil kebijakan, keputusan, serta tindakan-tindakan harus mengikuti nilai-nilai serta tujuan dari masyarakat itu sendiri. Dari sana, kemudian Howard R Bowen dijuluki sebagai "Bapak CSR" (Riyadi, 2007:6).

CSR tidak semata sebagai sebuah konsep namun lebih kearah "gerakan" yang fenomenal dewasa ini, oleh karenanya terlepas dari keberagaman pelaksanaannya, CSR sendiri dapat diartikan sebagai berikut:

1. Perusahaan swasta tidak hanya berorientasi kepada keuntungan (laba), namun juga memiliki tanggung jawab terhadap masyarakat.

2. Perusahaan mempunyai konsituten yang lebih luas, tidak hanya sekedar para stakeholder.

3. Perusahaan hendaknya mampu membangun relasi dengan masyarakat di berbagai aspek dan tidak semata melalui pasar semata.

4. Bisnis berkewajiban untuk memberikan pelayanan terhadap nilai-nilai kemanusiaan yang lebih luas cakupannya, tidak hanya sekedar nilai-nilai ekonomis tradisional yang mendominasi pasar. (Riyadi, 2007:6)

Sementara itu Teguh Sripambudi dalam Puspensos (2005:18) mengemukakan pengertian CSR sebagai sebuah komitmen dalam dunia usaha untuk memberikan kontribusi guna mendorong iklim pembangunan ekonomi yang berkelanjutan, bekerjasama dengan tenaga kerja dan organisasinya, dengan masyarakat lokal maupun masyarakat luas guna memberikan kualitas hidup yang lebih baik, dengan memberikan hal-hal yang menguntungkan kepada kedua belah pihak baik untuk kemajuan bidang usaha itu sendiri maupun untuk pembangunan.

\section{Pelaksanaan CSR dan manfaatnya bagi perusahaan}

Di Indonesia sendiri pelaksanaan dan perkembangan CSR mengalami beberapa pergeseran yang lebih membidik kepada bagaimana perusahaan dapat memberikan kemanfaatan dalam program CSR ini.Setiap perusahaan dapat melakukan berbagai strategi dalam melaksanakan CSR ini juga menjadikannya sebagai sebuah strategi pemasaran terpadu.

Adanya kesadaran terkait pentingnya melaksanakan CSR ini menjadi tren global seiring dengan semakin berkembangnya kepedulian masyarakat global terhadap produkproduk ramah lingkungan serta diproduksi dengan aturan-aturan sosial juga prinsip-prinsip hak asasi manusia (HAM).

Di Eropa ada sebuah kebijakan, di mana bank-bank di sana menerapkan kebijakan dalam pemberian pinjaman hanya kepada perusahaan yang menerapkan CSR dengan baik. Misalnya saja, bank-bank di Eropa hanya memberikan pinjaman kepada perusahaan- 
Diterbitkan oleh Program Studi Ilmu Komunikasi

Universitas Ahmad Dahlan Yogyakarta

perusahaan perkebunan di Asia apabila ada jamian dari perusahaan tersebut apabila tidak melakukan pembakaran hutan ketika membuka lahan perkebunan (Idris, 2005).

Hal tersebut setidaknya memberikan pelajaran, bahwa perusahaan-perusahaan harus senantiasa menjaga lingkungan sekitar dalam melakukan proses produksinya. Bukan sekedar mencari keuntungan profit dan mengabaikan lingkungan, namun bagaimana agar keduanya bisa selaras berkeseimbangan.

Pelaksanaan CSR memberikan manfaat bagi perusahaan-perusahaan sendiri. Setidaknya ada dua manfaat yang dapat diperoleh oleh perusahaan, yaitu: membangun reputasi perusahaan (corporate reputation). Setiap perusahaan tentu akan senang dan bangga apabila perusahaan mereka memiliki reputasi yang positif di mata masyarakat dan konsumennya.

Tumbuhnya rasa bangga (sense of pride) dari semua karyawan di sebuah perusahaan juga merupakan manfaat lain dari pelaksanaan CSR. Setiap karyawan tentu akan bangga apabila perusahaan tempatnya berkerja tidak hanya sekedar mencari keuntungan, namun juga mempunyai keinginan untuk mempersembahkan something beyond just money. Rasa bangga karyawan akan perusahaan dipercaya akan menghidupkan spirit serta dedikasi para karyawan untuk memberikan yang terbaik.

Seiring dengan perkembangannya, CSR dipercaya tidak hanya memberikan manfaat bagi perusahaan semata namun bagi orang dalam ataupun karyawan. Di mana tanggung jawab sosial ini dipercaya akan menumbuhkan rasa bangga dan percaya diri dari karyawan. Dengan adanya CSR, citra perusahaan tentunya akan tertanam kuat di masyarakat. CSR merupakan investasi masa depan perusahaan.

Selama kurang lebih sepuluh tahun terakhir ini, di Indonesia sendiri hubungan antara perusahaan dengan masyarakat sekitar menjadi sebuah polemik tersendiri.Terutama dalam kaitannya dengan peranan maupun kontribusinya dalam turut serta penyelesaikan persoalan-persoalan masyarakat. Sejumlah fakta mengenai buruknya hubungan perusahaan dengan masyarakat sendiri pun seolah mempertegas hal ini, misalnya: perebutan lahan, ketimpangan sosial, minimnya kesempatan kerja, dan perampasan hak-hak asasi manusia oleh perusahaan.

CSR sebagai sebuah konsep yang ditawarkan untuk menjalin hubungan baik antara perusahaan dengan masyarakat menjadi sebuah solusi akan hal ini. CSR tidak hanya dijabarkan sebagai sebuah tanggung jawab sosial terhadap komunitas maupun masyarakat namun juga di sekitar wilayah kerja serta operasinya.

Perusahaan hendaknya dapat menyadari adanya kesalahan masa lalu yang dianggap represif untuk kemudian mambu membangun hubungan yang lebih baik, sehingga akan tercipta hubungan yang harmonis antara perusahaan dengan lingkungan strategisnya.

\section{Hasil Penelitian dan Analisis}

CSR sebagai sebuah strategi perusahaan telah dijalankan PT Madubaru sejak tahun 1991 dan tidak mengalami perubahan, hal ini dikarenakan strategi CSRdalam bentuk Kemitraan dan Bina Lingkungan ini merupakan himbauan pemerintah bagi setiap BUMN sebagai salah satu upaya untuk peningkatan kesejahteraan masyarakat. Meskipun strategi 
CSRdengan membentuk Program Kemitraan dan Bina Lingkungan ini merupakan himbauan pemerintah, namun PT Madubaru juga merasa tepat untuk melaksanakannya karena mampu mendatangkan kemanfaatan bagi perusahaan sendiri, seperti : adanya izin dari masyarakat terhadap keberadaan perusahaan, dukungan masyarakat ketika perusahaan sedang mengalami krisis, serta lingkungan perusahaan yang harmonis tidak terjadi aksiaksi anarkis yang merugikan perusahaan oleh masyarakat, seperti : huru-hara, demonstrasi dan sebagainya. Jika dahulu program ini bernamaPEGELKOP (Pembinaan Golongan Ekonomi Lemah dan Koperasi), setalah mengalami berbagai perubahan akhirnya nama yang hingga saat ini digunakan adalah PKBL (Program Kemitraan dan Bina Lingkungan).

Dalam melaksanakan Program Kemitraan dan Bina Lingkungan tersebut, telah ditetapkan sasaran wilayah oleh PT Madubaru dalam proses perencanaannya. Adapun sasaran wilayahnya adalah daerah-daerah di Daerah Istimewa Yogyakarta, baik: Bantul, Gunung Kidul, Sleman, Kulon Progo dan Kota Yogyakarta. Berikut adalah gambaran pelaksanaan program-program tersebut:

\section{Kemitraan}

Program ini dikemas dalam bentuk pinjaman bagi para pengusaha kecil dan menengah. Berbagai sektor usaha di Daerah Istimewa Yogyakarta, banyak yang telah menjadi mitra di PT Madubaru. Dengan mengajukan proposal pengajuan, maka dengan mudah para pengusaha kecil dan menengah tersebut dapat menerima pinjaman dengan proses survei terlebih dahulu. Proposal yang masuk, umumnya akan diajukan kepada Unit Keuangan untuk mendapat persetujuan, setelah disetujui barulah akan di survei tentang kelayakan usaha tersebut. Besarnya pinjaman bermacam-macam, tergantung dengan pengajuan dan ketersediaan dana. Ada yang hanya sebesar Rp 1.000.000,- sampai dengan Rp 100.000.000,-.

Proses survei dilakukan untuk menilai kelayakan para pengusaha dalam mengajukan pinjaman. Dari hasil survei baru akan diputuskan berapa nominal yang akan dipinjaman. Apabila usaha tersebut dinilai masih kecil dan belum berkembang, maka nantinya nominal yang diajukan akan dipotong sesuai dengan penilaian kelayakan. Hal ini sebagaimana yang disampaikan Pak Ruslani, sebagai berikut:

"Dari survei baru kita dapat menilai apakah usaha tersebut layak mendapatkan bantuan apa tidak. Kadang ada pula yang tidak sesuai, mengajukan terlalu besar namun saat disurvei ternyata usahanya masih kecil" (Wawancara Unit PKBL PT Madubaru).

Sementara itu besar kecilnya dana yang dikucurkan dalam Program Kemitraan ini memang berbeda-beda setiap tahunnya. Hal tersebut karena jumlah laba yang didapatkan perusahaan juga berbeda-beda, sebagaimana telah disebutkan di atas. Selain karena besar kecilnya laba yang diperoleh, adanya perbedaan jumlah dana yang digunakan juga disebabkan karena perubahan perundang-undangan itu sendiri. Jika di tahun 2013 pemerintah meminta setiap perusahaan negara (BUMN) untuk mengalokasikan 2\% dari laba yang diperoleh untuk pelaksanaan program ini, maka di tahun 2014 dinaikan menjadi 
Diterbitkan oleh Program Studi IImu Komunikasi

Universitas Ahmad Dahlan Yogyakarta

$4 \%$, dan di tahun 2015 ini diturunkan kembali menjadi 3\%. Hal ini sebagaimana yang disampaikan Pak Ruslani, sebagai berikut:

"Jumlah per tahunnya berbeda-beda. Hal tersebut, karena disesuaikan dengan laba yang didapatkan perusahaan setiap tahunnya. Peraturan pemerintah juga berubah-ubah, jika 2013 2\% dari laba, 2014 4\%, dan 2015 ini hanya 3\%”. (Wawancara Unit PKBL PT Madubaru )

Berikut ini adalah beberapa sektor usaha yang menjadi mitra PT Madubaru, sampai dengan September 2015 berdasarkan jenis usahanya:

Tabel 4.4

Daftar Mitra Binaan Berdasarkan Jenis Usaha

\begin{tabular}{|l|l|l|l|l|l|l|l|}
\hline Mitra Binaan & Industri & Dagang & Ternak & Perikn & Jasa & Pertan & Jml \\
\hline Badan Usaha & 0 & 0 & 0 & 0 & 0 & 0 & 0 \\
\hline Perorangan & 43 & 58 & 7 & 11 & 22 & 1 & 142 \\
\hline Kop.Karyawan & 0 & 0 & 0 & 0 & 1 & 0 & 1 \\
\hline Non.Kop.Kary. & 0 & 0 & 0 & 0 & 3 & 0 & 3 \\
\hline TOTAL & 43 & 7 & 11 & 26 & 1 & 146 \\
\hline
\end{tabular}

Sementara jika dilihat dari wilayahnya, berikut ini adalah sebaran wilayah usaha kecil menengah yang menjadi mita PT Madubaru, sampai dengan September 2015:

Tabel 4.5.

Daftar Mitra Binaan Berdasarkan Wilayahnya

\begin{tabular}{|l|l|l|l|l|l|l|}
\hline Mitra Binaan & Kodya & Bantul & Sleman & K.Progo & G.Kidul & Jml \\
\hline Badan Usaha & 0 & 0 & 0 & 0 & 0 & 0 \\
\hline Perorangan & 8 & 123 & 9 & 1 & 1 & 142 \\
\hline Kop.Karyawan & 0 & 2 & 0 & 0 & 0 & 2 \\
\hline Non.Kop.Karywn & 0 & 2 & 0 & 0 & 0 & 2 \\
\hline TOTAL & 8 & 127 & 9 & 1 & 1 & 146 \\
\hline
\end{tabular}

Jika dilihat dari tabel di atas, Kabupaten Bantul mempunyai jumlah yang paling banyak. Hal itu dikarenakan Kabupaten Bantul merupakan daerah prioritas dari Program Kemitraan ini. Mengingat PT Madubaru terletak di Bantul, maka segala program-program kemasyarakatan memang diprioritaskan untuk masyarakat di wilayah Bantul, terlebih di Desa Kasihan.

\section{Bina Lingkungan}

Bina Lingkungan merupakan sebuah program yang diwujudkan dalam bentuk bantuan-bantuan sosial kepada masyarakat. Sama dengan kemitraan, program ini juga merupakan anjuran pemerintah bagi setiap badan usaha milik negara (BUMN). Program ini dibagi dalam beberapa sendi, seperti: bencana alam, pendidikan, kesehatan, sarana prasarana umum, sarana ibadah, dan pelestarian umum. 
Program ini dilaksanakan berdasarkan pada usulan masyarakat. Hampir tidak ada program yang dinisiasikan sendiri oleh unit PKBL dalam program ini. Hal ini dikarenakan jumlah permintaan saja pada umumnya sangat banyak, bahkan sampai ada beberapa yang tidak dapat direalisasikan karena keterbatasan dana. Oleh karenanya hampir tidak ada yang dilakukan sendiri, semua yang dilaksanakan adalah sesuai dengan permohonan yang masuk ke unit PKBL. Khusus bagi bencana alam, karena memang tidak terduga maka pelaksanaan bantuan (charity) dalam sebuah bencana adanya inisiatif dari PT Madubaru sendiri, seperti halnya saat Gempa Bumi di Yogyakarta pada tahun 2006 atau Musibah Awan Panas di Yogyakarta juga pada tahun 2010 lalu.

Berikut ini, adalah beberapa program yang telah dilaksanakan oleh PT Madubaru dalam 5 tahun terakhir ini:

a. Pendidikan

Pemberian beasiswa kepada siswa berprestasi di tingkat SD dan SMP merupakan program rutin yang dilakukan oleh PT Madubaru. Di tahun 2015 ini PT Madubaru bekerjasama dengan Dinas Pendidikan Kabupaten Bantul memberikan kepada 32 siswa SD, SMP, dan SMA. 32 siswa tersebut diberikan beasiswa sebesar Rp 900.000,-/semester untuk SD dan Rp 1.800.000,-/semester untuk SMP dan Rp 2.400.000,-/semester untuk SMA.

Dalam memberikan beasiswa ini, PT Madubaru hanya sebatas menerima data dari Dinas Pendidikan Bantul. Adapun proses seleksi dan penjaringan siswa-siswa berprestasi tersebut dilakukan oleh Dinas Pendidikan Bantul sendiri. Sehingga PT Madubaru (Unit PKBL) ketika peneliti berikan pertanyaan lebih lanjut, mengenai apa dasar pemberian beasiswa tersebut tidak bisa menyebutkan dengan jelas. Mengingat PT Madubaru hanya mendapatkan data dari Dinas Pendidikan kepada siapa-siapa saja beasiswa tersebut layak untuk diberikan.

Gambar 4.1

Pemberian Beasiswa Kepada Siswa SD-SMA

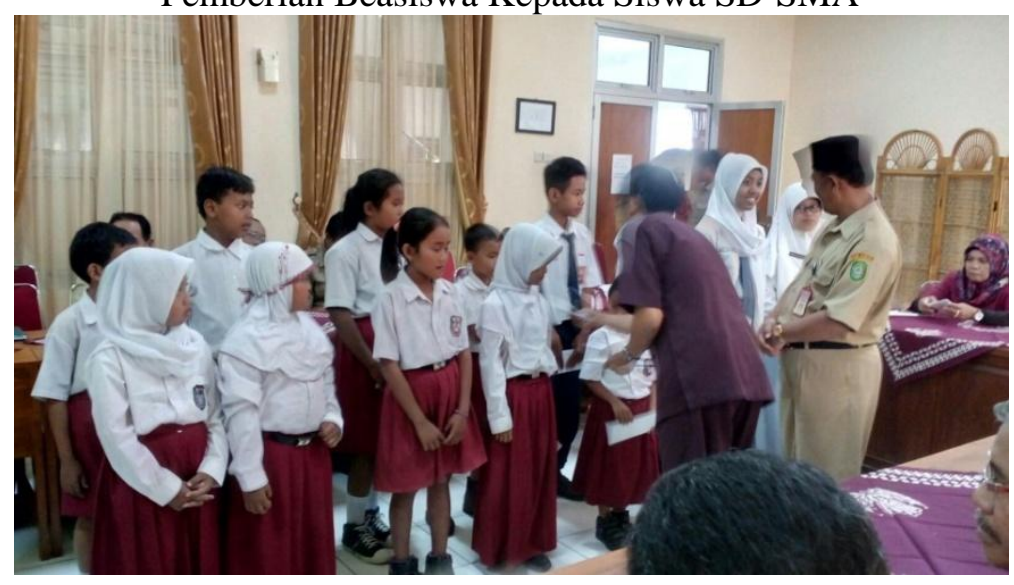

\section{b. Sarana Prasana}

Membangun sarana-prasana umum adalah salah satu program yang dilalukan PT Madubaru dalam melaksanakan Program Bina Lingkungan ini. Banyak sarana-prasana yang telah dibangun oleh PT Madubaru, seperti misalnya: perbaikan jalan, pembuatan selokan, pembangunan gapura, pembuatan toilet umum, dan lain sebagainya. 
Diterbitkan oleh Program Studi IImu Komunikasi Universitas Ahmad Dahlan Yogyakarta

Umumnya program-program pengadaaan sarana-prasarana ini adalah permintaan dari masyarakat sendiri yang menginginkan adanya perbaikan sarana-prasarana di tempat tinggal mereka. Dengan mengajukan permohonan kepada PT Madubaru, kemudian akan dilakukan survei terkait bisa tidaknya permohonan tersebut disetujui.

Jika program tersebut disetejui, maka kemudian masyarakat sendirilah yang melakukan pembangunan sarana-prasarana tersebut. PT Madubaru hanya sebatas memberikan dana dan monitoring terhadap pelaksanaan kegiatan pembangunan saranaprasarana.

Dengan adanya monitoring yang dilakukan, diharapkan proses pengerjaan saranaprasana dapat berjalan dengan baik, sesuai dengan harapan dari masyarakat. Monitoring ini tidak hanya dilakukan saat sarana-prasana sudah selesai di bangun, namun juga saat proses pengerjaan. Pak Ruslani dan Hanafi sendirilah yang melakukan proses monitoring terkait dengan pembangunan sarana-prasarana ini. Saat sudah selesai dibangun, pada umumnya akan ada prosesi peresmian bangunan tersebut. Adapun dari PT Madubaru sendiri, yang memimpin prosesi peresmian adalah Bapak Revianto Rares, Akt-Selaku Dirut Keuangan, akan tetapi tidak menutup kemungkinan apabila beliau berhalangan, Bapak Ruslani/Hanafi sendirilah yang melakukannya.

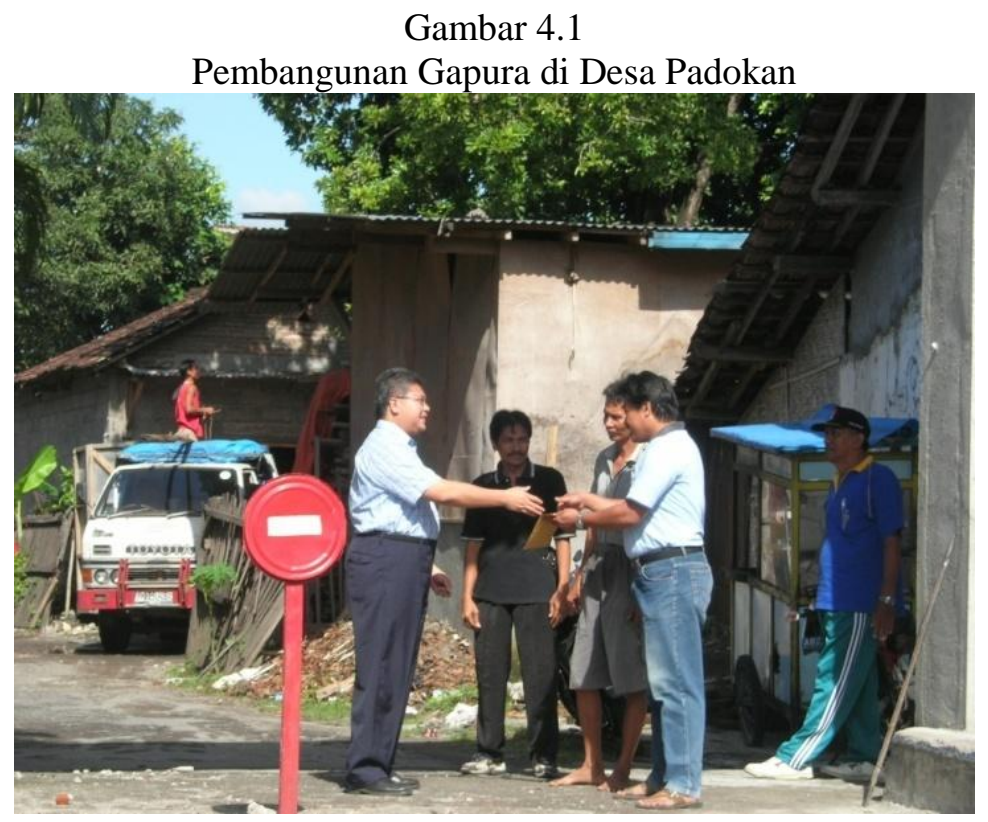


Gambar 4.2.

Pembangunan Selokan di Mrisi Bantul

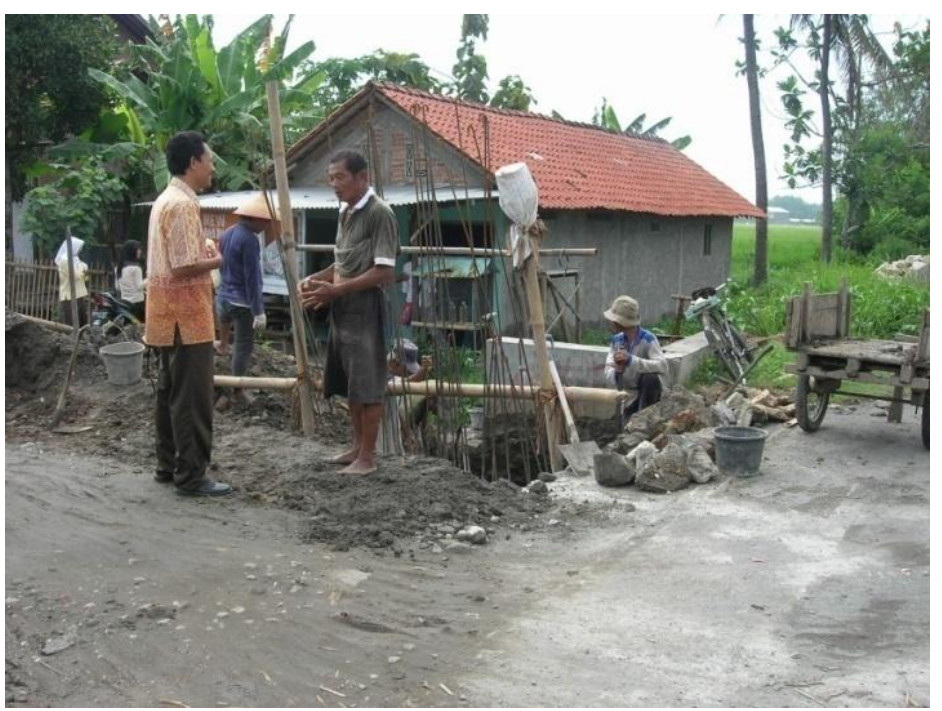

\section{c. Kesehatan}

Dalam bidang kesehatan, program PKBL ini diwujudkan dalam bentuk pengobatan gratis bekerjasama dengan Puskesmas Padokan. Pengobatan Gratis yang pernah dilakukan pada tahun 2012 yang lalu, banyak mendapatkan antusiasme dari masyarakat. Terbukti tidak kurang dari 500 masyarakat yang mengikuti pengobatan gratis tersebut. Ada yang memeriksa gula darah, tekanan darah, kolesterol, demam, flu, batuk, gigi, mata, dan lain sebagainya.

Gambar 4.4.

Pengobatan Gratis Kepada Masyarakat

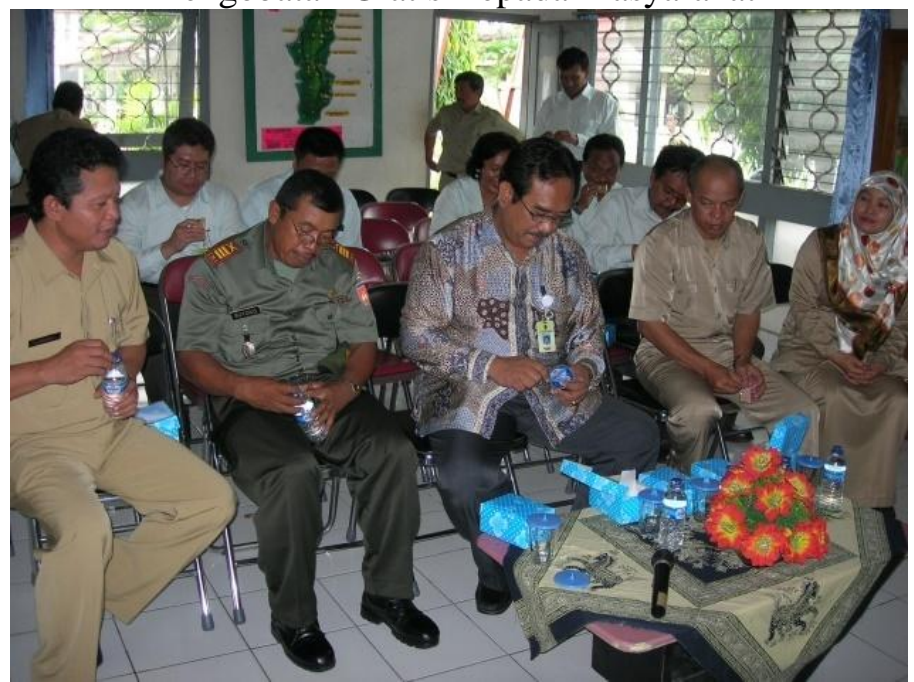


Diterbitkan oleh Program Studi IImu Komunikasi

Universitas Ahmad Dahlan Yogyakarta

\section{d. Pelestarian Lingkungan}

Upaya-upaya terhadap pelestarian lingkungan juga senantiasa dilakukan PT Madubaru. Salah satunya adalah dengan memberikan bibit-bibit tanaman ke warga Padokan. Pemberian bibit tanaman tersebut dilakukan, untuk menghijaukan daerah sekitar perusahaan. Pemberian bibit tanamanan dilakukan sendiri oleh Bapak Ruslani dan Hanafi selaku staff di unit PKBL, dengan mendatangi rumah-rumah warga di Desa Padokan Kasihan Bantul.

Masyarakat sendiri menerima baik pemberian bibit tanaman tersebut. Adapun bibit tanaman yang diberikan adalah bibit tanaman buah-buahan, dan obat-obatan. Ke depan pemberian tanaman ini diharapkan dapat ditingkatkan lagi cakupan wilayahnya, tidak hanya di daerah Padokan sendiri. Selain Unit PKBL, pemberian tanaman kepada masyarakat ini juga pernah dilakukan oleh Unit Pengelolahan Tanaman PT Madubaru. Tidak hanya sekedar membagikan tanaman kepada masyarakat, tetapi Unit Tanaman juga melakukan upaya edukasi kepada masyarakat terkait dengan pembudidayaan tanaman.

\section{e. Bantuan Sosial Lainnya}

Berbagai bantuan sosial kepada masyarakat juga seringkali dilakukan oleh Unit PKBL Madubaru. Beberapa diantaranya, adalah pemberian air bersih di Gunung Kidul, pemberian ambulance, pembangunan apotek, acara gatehering dengan masyarakat saat musim panen tebu, dan pemberian makanan maupun obat-obatan kepada korban bencana alam Gunung Merapi pada tahun 2010 yang lalu.

Selain memberikan bantuan sosial kepada masyarakat luas, PT Madubaru juga kerap kali memberikan bantuan kepada karyawan PT Madubaru sendiri. Hal ini dilakukan untuk meningkatkan kesejahteraan karyawan. Adapaun beberapa bantuan yang seringkali dilakukan oleh PT Madubaru kepada para karyawan diantaranya: pemberian beasiswa kepada anak-anak karyawan, rumah-rumah dinas untuk karyawan, pinjaman dana karyawan.

Upaya-upaya untuk meningkatkan kesejahteraan karyawan memang terus dilakukan oleh PT Madubaru, hal ini juga merupakan program CSR. Mengingat Program CSR tidak hanya dilakukan kepada masyarakat luar saja, namun tetapi juga internal perusahaan. Hal ini sebagaimana disampaikan oleh Bapak Ruslani, sebagai berikut:

"Program CSR tidak hanya dilakukan untuk masyarakat luar saja, tetapi juga diberikan kepada internal perusahaan. Beberapa program yang sudah dilakukan, diantaranya: pemberian beasiswa kepada anak-anak karyawan, rumah dinas, asuransi kesehatan, pinjaman dana, maupun juga dana pensiun". (Wawancara Unit PKBL). 
Gambar 4.6.

Pemberian Air Bersih di Gunung Kidul

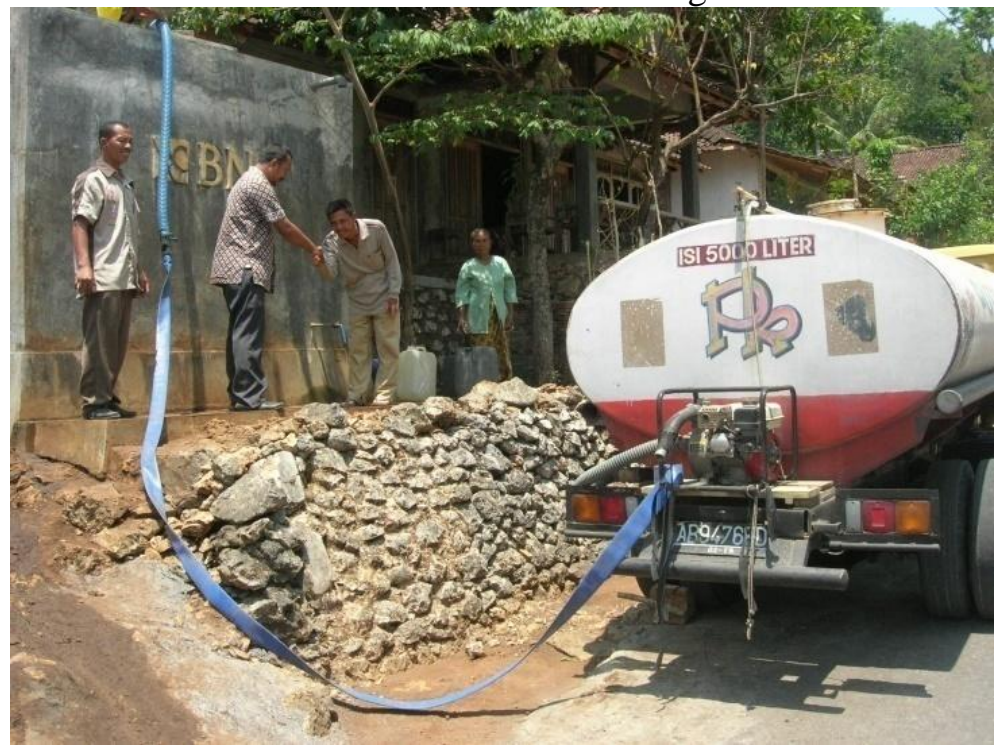

\section{Penutup}

Setelah melakukan penelitian terhadap Program CSR PT Madubaru, terkait dengan bagaimana strategi yang diterapkan oleh PT Madubaru dalam melaksanakan Program CSR guna menjalin hubungan baik dengan masyarakat. Peneliti mengambil kesimpulan, serta memberikan saran yang nantinya bisa digunakan sebagai evaluasi pagi perbaikan program CSR ke depannya.

\section{E. Kesimpulan}

Di dalam penelitian ini, peneliti dapat mengambil beberapa kesimpulan sebagai berikut:

1. Program CSR PG/PS Maduksimo yang dilakukan oleh Unit PKBL telah dilaksanakan dengan penuh perencanaan, adanya keterlibatan stakeholder, dan berkelanjutan.

2. Dalam melaksanakan Program CSR telah dibuat skala prioritas, terkait dengan program-program apa yang perlu didahulukan berdasarkan pada kepentingan masyarakat dan juga segmentasi dari masyarakat penerima program CSR tersebut. Di mana telah dibuat pembagian wilayah yang jelas, daerah-daerah mana saja yang menjadi obyek pelaksanaan Program CSR. Di mana daerah yang masih berada dalam 1 kelurahan yang (Kasihan) menjadi prioritas utamanya.

3. Adanya upaya-upaya pengembangan masyarakat sekitar dalam pelaksanaan Program CSR ini, seperti halnya membangun desa-desa binaan untuk mengembangkan kemandirian masyarakat dalam bertani, membangun usaha kecil, dan lainnya. 
Diterbitkan oleh Program Studi IImu Komunikasi

Universitas Ahmad Dahlan Yogyakarta

4. Belum adanya pemanfaatkan media digital (online) dalam proses pelaksanaan/pelaporan Program CSR di PT Madubaru. Padahal di Era Keterbukaan Komunikasi dan Informasi seperti sekarang ini, tentu hal tersebut merupakan sebuah strategi yang bisa dilakukan guna mengkomunikasikan pelaksanaan program CS kepada masyarakat luas, sehingga masyarakat bisa memberikan respon terkait dengan pelaksanaan program CSR ke depannya.

5. Belum adanya upaya untuk melakukan dialog (komunikasi) secara langsung kepada masyarakat sekitar dalam proses perencanan Program CSR ini. Hal ini tampak dari banyaknya permintaan masyarakat yang mengajukan sendiri bantuan sosial kepada PT Madubaru, namun karena satu dan lain hal tidak semua permintaan tersebut dapat dipenuhi. Mengingat dana yang ada sudah dialokasi dengan program lain. Jika saja ada upaya pendekatan dan komunikasi dengan masyarakat bisa dilakukan di awal saat perencanaan, tentu program yang dilaksanakan akan lebih sesuai dengan apa yang dibutuhkan masyarakat sendiri.

\section{F. Saran}

Berikut ini beberapa saran yang bisa peneliti berikan terkait dengan pelaksanaan Program CSR (Kemitraan dan Bina Lingkungan) PT Madubaru:

1. Pelaksanaan Program CSR PT Madubaru hendaknya lebih diutamakan pada program pengembangan masyarakat (community development). Dalam hal ini terkait bagaimana perusahaan bisa memberikan andil untuk meningkatkan kesejahteraan masyarakat sekitar secara berkelanjutan. Bukan hanya pada persoalan memberikan sarana prasarana maupun pembangunan infrastruktur masyarakat semata, namun lebih kepada bagaimana menghasilkan program yang dapat memberikan kemandirian bagi masyarakat sekitar untuk meningkatkan kesejahteraannya.

2. Membuka akses komunikasi dengan masyarakat, hal ini dimaksudkan untuk lebih mengetahui lagi kira-kira apa yang menjadi kebutuhan serta harapan dari masyarakat sekitar. Sehingga program yang dilaksanakan benar-benar merupakan program yang menjadi kebutuhan masyarakat. Bukan lagi menganggap bahwa program CSR adalah kewajiban semata, namun lebih kepada kebutuhan untuk memberikan kebermanfaatan atas adanya perusahaan di lingkungan masyarakat.

3. Pemanfaatan media-media baru, seperti halnya (website, media sosial) juga diperlukan dalam pelaksanaan Program CSR ini. Oleh karenanya, manajemen hendaknya mulai memikirkan untuk membuat webite resmi (official website/official social media) untuk mensosialisasikan Program CSR yang dilaksanakan kepada masyarakat luas. Sehingga masyarakat dapat berpartisipasi secara bebas dan terbuka dalam memberikan sumbang saran/pemikiran bagi pelaksanaan Program CSR ini. 


\section{Daftar Pustaka}

Baskin, Otis. 1997. Public Relations - The Profession and the Practise. Boston: McGraw Hill.

Bonar, S.K. 1997. Hubungan Masyarakat Modern. Jakarta: Rineka Cipta.

Coombs, W, Timothy. 2012. Managing Corporate Social Responsibility. London: British Library.

Cutlip, Scott M, Allen H. Center, and Glen M. Broom. 1985. Effective Public Relations. Englewood Cliffs: New Jersey.

Daft, Richard, L. 2006. Management. Jakarta: Salemba Empat

Djudju, Sudjana. 1992. Pengantar Manajemen Pendidikan Luar Sekolah. Bandung: Nusantara Press.

Edi Saputro, Bambang, dkk. 2005. Handbook 50 Tahun PG Madukismo. Yogyakarta: PG Madukismo.

Effendy, OnongUchana. 1992. Hubungan Masyarakat Modern. Jakarta: Bina Aksara. Handroko, dkk. 2007. Agrowisata PT Madubaru. Bantul: PT Madubaru.

Herimanto, Bambang. 2007. Public Relations dalamOrganisasi. Yogyakarta: Santusta.

Iriantara, Yosal. 2004. Community Relations-Konsep dan Aplikasinya. Bandung: Simbiosa Rekatama Media.

Kasali, Rhenald. 2000. Manajemen Public Relations. Jakarta: Grafiti.

LexyJ.Moleong. 1989.Metodologi Penelitian Kualitatif. Bandung: Rosdakarya

Mulyana, Deddy. 2004. Metode Penelitian Kualitatif. Bandung: Rosdakarya.

Nazir, Moh. 1999. Metode Penelitian. Jakarta: Ghalia Indonesia

Setyodarmodjo, Soenarko. 1997. Public Relations-Pengertian Fungsi dan Peranannya. Surabaya: Papyrus

Soemirat, Soleh. 2007. Dasar-Dasar Public Relations. Bandung: Rosdakarya.

Wheelen, Thomas L \& Hunger, J. David. 1995. Strategic Management and Business Policy. Reading, Mass: Addison - Wesley Publishing Company.

Wilcox, Dennis. 2003. Strategies and Tactics - Seventh Edition. United States: Routledge. Yin K.Robert. 2002. Studi Kasus Desain dan Metode. Jakarta: Grafindo Persada.

Browsing:

http://www.jkpp.org/Content.asp?id=286\&mid=131

www.crs.com., Corporate Social Responsibility danImplementasinya 